\title{
CORRELATION BETWEEN BIOCHEMICAL AND VIRAL REPLICATION INDICES IN CHRONIC ASYMPTOMATIC HBSAg POSITIVE INDIVIDUALS.
}

Narendra Gouda. B ${ }^{1}$, Shrikanth Reddy Bogle ${ }^{2}$

\section{HOW TO CITE THIS ARTICLE:}

Narendra Gouda. B, Shrikanth Reddy Bogle. "Correlation between biochemical and viral replication indices in chronic asymptomatic HBsAg positive individuals". Journal of Evolution of Medical and Dental Sciences 2013; Vol2, Issue 27, July 8; Page: 4950-4955.

\begin{abstract}
OBJECTIVE: To establish the relationship between biochemical, serological and viral replication indices in an individual with incidentally detected asymptomatic HBsAg positive. METHOD: This cross-sectional study was undertaken on 73 asymptomatic HBsAg positive individuals between January 2010 and December 2011. They were divided into 5 groups on the basis of HBeAg status, ALT levels, and HBV DNA levels. RESULTS: There was statistically significant difference in HBV DNA levels and ALT between HBeAg positive and negative; and in ALT levels between cases in Group C and E and that between Groups C \& D. There were significant difference in DNA levels between group D \& group E and that between group C \& group E. HBV DNA levels Corelated significantly with grade $(r=0.48, p<0.001)$ with Stage $(r=0.47, p<0.001)$ with ALT $(r=$ $0.37, \mathrm{p}<0.001)$ and AST $(\mathrm{r}=0.42, \mathrm{p}<0.001)$. AST co-related significantly HBV DNA levels. There was NO statistically significant difference in HBV DNA levels in cases with elevated ALT( $>40 \mathrm{IU} / \mathrm{ml}$ ) and those with normal ALT $(<40 \mathrm{IU} / \mathrm{ml})$. CONCLUSION: ALT and AST had a strong correlation with HBV DNA level.
\end{abstract}

INTRODUCTION: Hepatitis B Virus (HBV) infection and its sequel are serious public health problems worldwide. Around 2 billion people are infected by hepatitis B virus (HBV) worldwide of which 400 million persons suffer chronic infection with HBV. ${ }^{1} \mathrm{HBV}$ infection is usually clinically in apparent. Approximately, 5-10\% of infected adults develop chronic liver disease of varying severity. More than $90 \%$ of infants infected during the first year of life and 30-50\% children infected between 1-4 yrs of age develop chronic infection. The risk of death from HBV related liver cancer and cirrhosis is approximately $25 \%$ in persons who become chronically infected during child hood.2, $315-40 \%$ of carriers will develop serious complications during lifetime like cirrhosis, decompensated liver disease or HCC. ${ }^{1}$ 75\% of carriers are present in Asia. India has the second largest pool of HBsAg carriers after China.

AIMS AND OBJECTIVES: This study was undertaken to establish the relationship between biochemical, serological, viral replication indices in an individual with incidentally detected asymptomatic HBsAg positive.

MATERIAL AND METHODS: This study was undertaken in 112 asymptomatic subjects incidentally detected to be HBsAg positive and 39 patients were lost on follow up, so we limited our study to 73subjects. We included 73 subjects with ALT levels less than five the upper limit of normal, attending the outdoor facility of Department of Medicine, Vijayanagara Institute of Medical Sciences, Bellary, Karnataka, between January 2010 to December 2011. Their clinical, biochemical assessment was done. 


\section{ORIGINAL ARTICLE}

Inclusion Criteria: HBsAg positivity on 2 occasions. IgM Anti-HBc negative. ALT ( $<5$ times normal). Exclusion Criteria: History of jaundice $<1$ year, Presence of Ascitis.GI Bleeding, Hepatic Encephalopathy, Pregnant women and also those with immunodeficiency (renal/bone marrow transplant recipients or those on cancer chemotherapy / Hemodialysis. Co-infection with HIV or Hepatitis C. Alcohol consumption $\geq 20$ gm/day for $>5$ year. The study was approved by the ethics committee of Department of Medicine, Vijayanagara Institute of Medical Sciences, Bellary.

All the subjects were interviewed on the basis of a pre designed questionnaire regarding occupation, exposure to unsterilized needle and syringes. Blood transfusion, post history of Jaundice (etiology and outcome) any family member suffering from Hepatitis B/C/E, history of ingestion of any hepatotoxic drugs, alcohol injection (amount, since how many year), any surgical procedure, high risk behaviors as intravenous drug abuse, sexual promiscuity, family history of chronic liver disease, tattooing shaving razor, blade etc. none of the patients had a history of Hemodialysis or organ transplantation. Detailed general examination was carried out to look signs of chronic liver disease.

All the subjects serum were tested for serum Bilirubin, ALT,AST, HBeAg, IgM anti-HBc, anti HCV, HIV, and HBV DNA (quantitative by PCR)

The subjects were divided into following groups :Group A(6):HBeAg positive, HBV DNA >105, ALT $\geq 40$ (ie 40IU/ml).Group B(4):HBeAg positive, HBV DNA >105, ALT < 40.Group C(12):HBeAg negative, HBV DNA $\geq 10000$ copies/ml, ALT $\geq 40$.Group D(16):HBeAg negative, HBV DNA $\geq 10000$ copies/ml, ALT<40.Group E(35):HBeAg negative, HBV DNA <10000 copies/m, ALT <40.

Biochemical parameter (ALT, AST, Serum Bilirubin ) were measured using an antoanalyser. Prothrombin time was measured using Quick method.

The sera of the subjects were tested for HBsAg, IgM HBcAg, HBeAg and Anti-HBe (VIDAS automated module using enzyme linked Fluorescent immunoassay [ELFA], biomerieux Sa, France) anti HCV ( $3^{\text {rd }}$ generation ELISA Kit, ELISCAN ${ }^{\text {TM }}$ HCV), HIV I and II and p24 [MINI VIDAS (ELFA)] and HIV DUO ULTRA (HIV5).

Test for HBV DNA was done in sera of all subjects from using "Real Time Polymerase Chain Reaction". It involves the specific amplification of a $134 \mathrm{bp}$ region of the HBV genome. This analysis is done on Rotor Gene 3000 by using the highly sensitive \& specific TAQMAN assay method. The TAQMAN probes are used for fluorescent detection of only target sequence specific amplicons generated during PCR. Amplified products are indicated by Threshold Cycle (Ct) in amplification curve. The analytical detection limit of the test is $3.8 \mathrm{IU} / \mathrm{ml}(26.6 \mathrm{copies} / \mathrm{ml})$.

RESULTS: Statistical analyses were carried out using the statistical program for social sciences (SPSS). Pearson correlation was carried out. Two tailed value of less than 0.05 was considered statistically significant. Independent t-test was carried for testing the significance between two variables. Results are presented as mean $+\mathrm{SD}$.

A total of seventy three cases( 57 males and 16 females with mean age of $32.84+10.23$ years and $32+15.81$ years respectively) cases were included in the study, as they could complete the desired protocol.

In our study Ten cases were $\mathrm{HBeAg}$ positive (13.7\%)and HBV DNA positive and sixty-three were HBeAg negative (86.3\%) individuals of whom nineteen (26\%)cases were HBV DNA negative 
( $<26.6$ copies/ml). There was statistically significant difference in grade, HBV DNA levels and ALT but, there was no significant difference in the stage and age between the two groups.

In our study there were $6(8.2 \%)$ individuals in group A, 4 (5.5\%) in group B, $14(19.2 \%)$ in group C, 15 (20.5\%) in group D and 34(46.6\%) individuals in group E. There was no statistically significant difference between the Groups C and D in HBV DNA levels, AST, though there was statistically significant difference in ALT levels between the 2 groups. Also there was statistically significant difference in ALT levels between cases in Group C and E. There were significant difference in DNA levels between group D \& group E and between group C \& group E. Other groups were not tested for their statistical significance as there were too few in number.

HBV DNA levels ranged from $<26.6$ to $2.5 \times 10^{7}$ copies $/ \mathrm{ml}$

All the individuals were negative for IgM HBcAg, HIV and anti-HCV.

The ALT levels ranged from 14 to $85 \mathrm{IU} / \mathrm{ml}$. There were twenty cases with elevated ALT i.e. > $40 \mathrm{IU} / \mathrm{ml}$ and thirty-four cases with normal ALT i.e. $<40 \mathrm{IU} / \mathrm{ml}$. There was NO statistically significant difference in HBV DNA levels, grade and stage in cases with elevated and normal ALT. There was no correlation of ALT with HBV DNA, Grade and Stage.

The AST level ranged from 13 to $92 \mathrm{IU} / \mathrm{ml}$. There was significant co-relation of AST with HBV DNA levels, grade and stage of liver disease

There was also statistically significant co-relation of ALT ( $r=0.37, \mathrm{p}<0.001)$ and AST $(r=0.42, p$ $<0.001$ ) with HBV DNA levels. There was no correlation between HBV DNA levels with Age of the patient.

DISCUSSION: Hepatitis B is an important cause of Acute and chronic liver disease in the world . The aim of this study was to determine the relationship between biochemical, serological, and viral replicative indices in an incidentally detected asymptomatic HBsAg positive.

The Natural history of HBsAg carrier is in Asian Countries is different from that of the Western Countries. In the west a number of studies have demonstrated the benign outcome of HBsAg carries Manno et al 4, Reinicke et al 5, Koretz et al 6, Villeneuve et al7, Dragosiscs et al 8, de Francis et al 9. This favorable outcome hasn't been shared by similar studies conducted in the Asian region Will et al ${ }^{10}$, Hsu et al ${ }^{11}$, Beasly et al ${ }^{12}$, Obata et al ${ }^{13}$.

In the present study there were $10 \mathrm{HBeAg}$ positive constituting $13.7 \%$ of the total study group with a mean age of $27.5+8.62$ years and $63 \mathrm{HBeAg}$ negative individuals constituting $86.3 \%$ of the total with a mean age of 33.6+11.79 years. Though difference in age was present, similar to other studies in which HBeAg negative individuals were older than HBeAg positive, the difference was not statistically significant in the present study group. This is in discordance with earlier studies by Jie et al ${ }^{14}$ Manesis et al ${ }^{15}$, Yuen et al ${ }^{16}$, Chan et al ${ }^{17}$, who all had demonstrated that HBeAg negative cases are older than HBeAg negative. This may be due to the small number of cases in the present study. In the present study HBV DNA was negative in 19 patients while in the remaining fifty-four cases had HBV DNA ranging from 119 to $2.5 \times 10^{7}$ copies/ml. The wide variation in HBV DNA levels could be explained by that HBV isolates have different genetic subtypes, quasispecies, viral mutation and different immune ability to HBV Yao et al 18

In the present study a correlation was found between HBV DNA levels and ALT, AST in both HBeAg positive and HBeAg negative individuals. The correlation co-efficient was high. Habersetzer et al 20 . 
Iloeje et al ${ }^{19}$ had shown that patients with e-antigen negative chronic HBV infection have fluctuating ALT levels and one point estimation of ALT may not be reliable. Keeffe et al ${ }^{21}$ showed that patients with normal ALT may be associated with significant fibrosis especially in patients with a negative chronic HBV infection. ALT elevation in chronic hepatitis B patients may occur spontaneous or drug induced seroconversions or due to superadded insult with other viruses or drug. Perrilo et al ${ }^{22}$. With the help of the above mentioned information, it is reasonable to conclude that the ALT levels have poor predictability for progression of liver disease and planning treatment in patients with CHB.

In conclusion we can say that HBV DNA levels (PCR) is better in determining disease activity and in guiding treatment of asymptomatic HBsAg positive individuals than ALT levels.

\section{BIBLIOGRAPHY:}

1. Lee WM: Hepatitis B virus infection. N Engl J Med 1997, 337:1733-1745.

2. World Health Organization. Hepatitis B: Factsheet No. 204. Geneva. WHO 2000 (Oct): 1-2.

3. Anatnarayn R, Jayaram Paniker CK. Hepatitis viruses. In : Ananthanarayan R, Paniker CK, eds. Textbook of microbiology 5th edition. Chennai. M/s Orient Longman (India) 1997: 508-19.

4. Manno M, Camma C, Schepis F, Bassi F, Gelmini R, Giannini F, et al. Natural history of chronic HBV carriers in northern Italy: morbidity and mortality after 30 years. Gastroenterology 2004; 127:756-763.

5. Reinicke V, Dybkjaer E, Poulsen H, Banke 0, Lylloff K, Nordenfelt E. A study of Australiaantigen-positive blood donors and their recipients, with special reference to liver histology. N Engl J Med 1972; 286: 867-70.

6. Koretz RL, Lewin KJ, Rebhun DJ, Gitnick GL. Hepatitis B surface antigen carriers - to biopsy or not to biopsy. Gastroenterology 1978; 75: 860-3.

7. Villeneuve JP, Richer G, Cote J, Guevin R, Marleau D, Joly JG, et al. Chronic carriers of hepatitis B antigen (HBsAg). Histological, biochemical, and immunological findings in 31 voluntary blood donors. Am J Dig Dis 1976; 21: 18-25.

8. Dragosics B, Ferenci P, Hitchman E, Denk H. Long-term follow-up study of asymptomatic HBsAg positive voluntary blood donors in Austria: a clinical and histologic evaluation of 242 cases. Hepatology 1987; 7: 302-6.

9. de Franchis R, Meucci G, Vecchi M, Tatarella M, Colombo M, Del Ninno E, et al. The natural history of asymptomatic hepatitis B surface antigen carriers. Ann Intern Med 1993; 118: 191-4.

10. Will H, Reiser W, Weimer T. Replication strategy of human hepatitis B virus. J Virol 1987; 61:904-11.

11. Hsu YS, Chien RN, Yeh CT, Sheen IS, Chiou HY, Chu CM, et al. Long-term outcome after spontaneous HBeAg seroconversion in patients with chronic hepatitis B. HEPATOLOGY 2002;35:1522-1527.

12. Beasley RP, Hwang LY, Lin CC, Chien CS. Hepatocellular carcinoma and hepatitis B virus. A prospective study of 22707 men in Taiwan. Lancet 1981; ii : 1129-33.

13. Obata H, Nishioka K. Prevalence of hepatitis B virus and primary hepatocellular carcinoma in Asia. Southeast Asian J Trop Med Public Health 1979; 10 : 621-6. 
14. Jie Shao, Lai Wei, Hao Wang, Yan Sun, Lan-Fang Zhang, Jing Li, Jian-Qiang Dong : Relationship between hepatitis B virus DNA levels and liver histology in patients with chronic hepatitis B : World J Gastroenterol 2007 April 14;13(14): 2104-2107.

15. Manesis EK, Papatheodoridis GV, Sevastianos V, Cholongitas E, Papaioannou C, Hadziyannis SJ. Significance of hepatitis B viremia levels determined by a quantitative polymerase chain reaction assay in patients with hepatitis $B$ e antigen-negative chronic hepatitis $B$ virus infection. Am J Gastroenterol 2003; 98: 2261-2267 PubMed.

16. Yuen MF, Ng IO, Fan ST, Yuan HJ, Wong DK, Yuen JC, Sum SS, Chan AO, Lai CL. Significance of HBV DNA levels in liver histology of HBeAg and Anti-HBe positive patients with chronic hepatitis B. Am J Gastroenterol 2004; 99: 2032- 2037 PubMed

17. Chan HL, Tsang SW, Liew CT, Tse CH, Wong ML, Ching JY, Leung NW, Tam JS, Sung JJ. Viral genotype and hepatitis B virus DNA levels are correlated with histological liver damage in HBeAg-negative chronic hepatitis B virus infection. Am J Gastroenterol 2002; 97: 406-412.

18. Yao Xie, Hui Zhao, Wang-Su Dai and Dao-Zhen Xu: HBV DNA level and antigen concentration in evaluating liver damage of patients with chronic hepatitis B. HBPD Int 2003; 2 : 418 422141.

19. Iloeje UH, Yang HI, Su J, Jen CL, You SL, Chen CJ, et al . The risk evaluation of viral load elevation and associated liver disease/cancer. Gastroenteroly 2006; 130:678-86.

20. Habersetzer F, Zoulim F, Jusot JF, et al. Clinical evaluation of the branched DNA assay for hepatitis B virus DNA detection in patients with chronic hepatitis B e antigen and treated with interferon-alpha. J Viral Hepat 1998; 5:407-414.

21. Keeffe EB, Dieterich DT, Han SH, Jacobson RM, Martin P, Schiff ER, et al . A treatment algorithm for the management of chronic hepatitis B virus infection in the United States: an Update. Clin Gastroenterol Hepatol 2006; 4:936-62.

22. Perrilo RP. Acute flares in chronic hepatitis B: The natural and unnatural history of an immunologically mediated liver disease. Gastroenterology 2001; 120:1009-22.

TABLE 1: COMPARISON OF HBV DNA LEVEL, ALT, AST IN CASES WITH HBeAg POSITIVE AND NEGATIVE

\begin{tabular}{|l|l|l|l|l|l|l|}
\hline Factor & HBeAg & $\mathbf{N}$ & Mean & Std. Deviation & Std. Error Mean & P \\
\hline \multirow{2}{*}{$\begin{array}{l}\text { HBV DNA } \\
\text { (copies/ml) }\end{array}$} & Positive & 10 & 14910410.00 & 7102572.426 & 2246030.611 & \multirow{2}{*}{$<0.05$} \\
\cline { 2 - 6 } & Negative & $44^{*}$ & 244983.68 & 587039.604 & 88499.550 & \\
\hline \multirow{2}{*}{$\begin{array}{l}\text { AGE } \\
\text { (in years) }\end{array}$} & Positive & 10 & 27.5000 & 8.61846 & 2.72539 & \multirow{2}{*}{$>0.05$} \\
\cline { 2 - 7 } & Negative & 63 & 33.6032 & 11.79330 & 1.48582 & \\
\hline \multirow{2}{*}{ ALT (IU/ml) } & Positive & 10 & 59.20 & 27.259 & 8.620 & \multirow{2}{*}{$<0.05$} \\
\cline { 2 - 7 } & Negative & 63 & 32.77 & 13.959 & 1.759 & \\
\hline \multirow{2}{*}{ AST(IU/ml) } & Positive & 10 & 50.9000 & 24.76310 & 7.83078 & \\
\cline { 2 - 7 } & Negative & 63 & 26.4730 & 10.06055 & 1.26751 & \\
\hline
\end{tabular}

*HBV DNA was Negative i.e. (<26.6 copies/ml) in 19 cases. 
TABLE 2: SHOWING NUMBER OF CASES, MEAN AGE, ALT, AST and HBV DNA IN EACH GROUP

\begin{tabular}{|l|l|l|l|l|l|}
\hline GROUP & Frequency & $\begin{array}{l}\text { Mean } \\
\text { ALT } \\
(\mathbf{I U} / \mathbf{m l})\end{array}$ & $\begin{array}{l}\text { Mean } \\
\text { AGE }\end{array}$ & $\begin{array}{l}\text { HBV Dean } \\
\text { (Copies } \\
\text { ml) })\end{array}$ & $\begin{array}{l}\text { Mean } \\
\text { AST } \\
\text { (IU/ml) }\end{array}$ \\
\hline A & 6 & 80.00 & 25.6667 & 16741900.00 & 68.0000 \\
\hline B & 4 & 28.00 & 30.2500 & 12163175.00 & 25.2500 \\
\hline \multicolumn{1}{|c|}{ C } & 14 & 54.54 & 32.7857 & 184937.36 & 41.3714 \\
\hline D & 15 & 26.73 & 38.667 & 543018.27 & 23.0000 \\
\hline E & 34 & 26.47 & 31.7059 & $2992.33^{*}$ & 21.8706 \\
\hline Total & $\mathbf{7 3}$ & $\mathbf{3 6 . 3 9}$ & $\mathbf{3 2 . 7 6 7 1}$ & $\mathbf{2 9 6 0 8 0 3 . 3 7}$ & 29.8192 \\
\hline
\end{tabular}

*HBV DNA was Negative i.e. $(<26.6$ copies/ml) in 19 cases of Group E.

TABLE 3: COMPARISON OF CASES WITH ELEVATED AND NORMAL ALT WITH HBV DNA LEVELS, GRADE, STAGE AND AST

\begin{tabular}{|c|c|c|c|c|c|c|}
\hline & ALT & $\mathbf{N}$ & $\begin{array}{l}\text { Mean } \\
\text { (copies/ml) }\end{array}$ & $\begin{array}{l}\text { Std. Deviation } \\
\text { (copies/ml) }\end{array}$ & $\begin{array}{l}\text { Std. Error } \\
\text { Mean } \\
\text { (copies } / \mathrm{ml} \text { ) }\end{array}$ & $\mathbf{P}$ \\
\hline \multirow{2}{*}{ DNA } & $>40$ & 20 & 5152026.15 & 8188966.486 & 1831108.573 & \multirow{2}{*}{$>0.05$} \\
\hline & $<40$ & 34 & 1671848.79 & 4907189.807 & 841576.109 & \\
\hline \multirow{2}{*}{$\begin{array}{l}\text { AST } \\
(\mathrm{IU} / \mathrm{ml})\end{array}$} & $>40$ & 20 & 49.3600 & 15.67104 & 3.50415 & \multirow{2}{*}{$>0.05$} \\
\hline & $<40$ & 53 & 22.4453 & 5.81585 & 0.79887 & \\
\hline
\end{tabular}

\section{AUTHORS:}

1. Balaji Arumugam,

2. Saranya Nagalingam

\section{PARTICULARS OF CONTRIBUTORS:}

1. Assistant Professor, Department of Medicine, Vijayanagar Institute of Medical Sciences, Bellary, Karnataka.

2. Consulting Physician, Department of Medicine, Jindal Sanjeevani Hospital, Torangallu, Bellary, Karnataka.
NAME ADRRESS EMAIL ID OF THE CORRESPONDING AUTHOR:

Dr. Narendra Gouda .B

Assistant Professor, Department of Medicine, Vijayanagara Institute of Medical Sciences, Bellary, Karnataka Pin 583104

Email: purnaren78@yahoo.com

Date of Submission: 02/07/2013. Date of Peer Review: 02/07/2013. Date of Acceptance: 03/07/2013. Date of Publishing: 06/07/2013 